\title{
Rationalists' Concept of Mental Activity: The Cartesian Example
}

\author{
Francis Israel Minimah Ph.D \\ Department of Philosophy, University of Port Harcourt, Nigeria
}

\begin{abstract}
The philosophical criticisms of the last two centuries have prosecuted a very searching analysis of the cognitive capacity of the human mind to know if there is a real world outside the mind. With the transition to the modern period, there was enormous transformation in the conception of thinking and knowing. Philosophers of some certain persuasions began to set the philosophical agenda to understand the objective world based on the foundations of rationalism. These philosophers have insisted that the human mind naturally possess innate ideas, principles or capacity to know things independent of sense - experience. Given these antecedence, this paper extrapolates the rationalists' concept of mind using the Cartesian example as a case study ${ }^{l}$. It argues that for Descartes, the deliverances of external objects by the senses are deceptive and cannot lead us to the true knowledge of things. For him, the human mind possesses the modalities of thought and has at its disposal certain innate principles produced by the mechanism of reasoning that lead to our knowledge of the world. His attempt to investigate the cognitive activities of the subject as the key source of understanding the objective universe opens the door to the development of an epistemology that sees the mind as a 'productive' process. In this way, Descartes' theory of mind and consciousness represents a move away from the investigation of reality (the structures, categories of reality/object) as conceived by classical philosophers to the investigation of the knowing process (the structures, categories of the knowing process/subject) as initiated by modern philosophers.
\end{abstract}

\section{Introduction}

From the Ancient period, the cognitive process by which the human mind comes by our knowledge of reality has been a central issue in philosophy. In analyzing this issue, philosophers have examined the relation between the subject and act or process of consciousness or cognition on one hand and the object of which the subject is made aware of this act or process on the other hand. Answers to this question has raised other sorts of questions about the modes of our cognitive process, the nature of intentionality, the character of mental representation, the immediacy of our apprehensions of reality, the degree to which cognition is active or passive, the characteristics of objectivity and universality in the concepts and judgements formed by our individual minds, the causal connection between object and percipient and the ultimate grounds of our spontaneous belief that we can and do attain certain knowledge concerning the real nature of the universe in which we live. In extolling of the function of the minds abstract intellectual thought, Plato $(347-427)$ argues that the human mind can grasp objects conceptually because only what has conceptual forms has existing reality. Conceptual forms are the structures of reality itself. For Aristotle, as generally in all other Greek - Classical philosophers, thinking and knowing presuppose an object outside of human consciousness which can be grasped, touched, represented and mirrored with certainty. Aristotle's argues that there is no knowledge in the human mind which does not come through the senses. The senses, he says are the sources through which knowledge gets to the mind. The object of intellectual thought which were for Plato realities transcending the domain of sense experience, Aristotle proclaimed to be really immanent in the data of the latter. True knowledge, for him is the conformity of the mind with reality; thus acknowledging the respective contributions of the intellect and sensation as the mind's cognitive activities.

Over the course of the medieval period, a comprehensive and powerful account about the nature of mind and of human knowledge became more and more prominent from St Augustine (354 - 430) who borrowed considerable ideas from the philosophical teachings of Plato and Aristotle to the days of the Carlovingian revival of learning with Alcuin (735 - 804), Scotus Eriugena (815 - 880) and St. Anselm (1033 - 1109), to the golden age of scholasticism in the thirteenth century that began with St. Bonaventure $(1221-1274)$, Albertus Magnus (1193 - 1280), Dun Scotus (1266 - 1308) and St. Thomas Aquinas (1224 - 1274) etc who attempted in various ways to formulate a more traditional and clearly christian theology of human cognition. Writing on the obsession of medieval mind, Robert Pasnau writes:

Medieval theologians took particular interest in human cognition both as a way of establishing the epistemological foundations of theology and as a way of coming to know and to understand God. Both of these strands are present in medieval Christian philosophy from its beginning in Augustine 2 . 
In one of his earliest writings, the Contra Academicos, Augustine sets out to refute the arguments of the Ancient academic school of scepticism and thereby establish the feasibility of the human rational inquiry into the truth. Later in his De Trinitate, Augustine discusses the human mind at length - not just to understand it in its own right but more importantly as a model for understanding the Trinity. For medieval philosophers therefore, the study of cognition was not just an end in itself but a way of exploring the foundation of knowledge. Here, the human mind was conceived as applying rational discourse to the mysteries of faith in an attempt to understand the world - therein they imagined, was the ultimate explanation of reality. Consequently, medieval theologians seeking to understand God took understanding the world as substantial part of their theological project. In this way, the human soul, the spiritual element of human beings was taken as a reflection of the divine. Bonaventure for instance, writes that if you consider the souls' three powers "you will be able to see God through yourself as though an image"3. St. Aquinas further argues that "the intellectual light in us is nothing other than a particular shared likeness of the uncreated light"4.

Arguing from an apparent apposite direction, scientists and philosophers of some rational persuasions from the beginning of the modern period broke away from the medieval past to conceive reality as nature. According to W.T. Jones:

The most momentous element in the great change from medieval to modern times was the development of scientific method ... if it can be said that classical philosophy was overthrown by the Christian discovery of God, then it can be said that medieval philosophy was overthrown by the scientists' discovery of nature. ${ }^{5}$

But what was this nature which science tried to explain and how was it related to the philosophy of the early modern period? To respond to this question, we will consider the development of the scientific methods and its relation impact on philosophy. From the fifteenth century, the Renaissance, the Reformation culminating in the rise of science were periods of great intellectual progress which saw among many other things, the inventions of printing and advancements in scientific investigation, in astronomy and geographical discoveries such that this intellectual mood opened a new conception of the universe and created the need to analyze the structure of nature. For the modern man, the human mind no longer conceived the universe as a world created by an invisible omnipotent designer but as an object that could be studied, as a vast set of facts standing in relation to man as a given to be analyze by the scientific methods. Using the Aristotelian - Baconian empirical inductive method of science - a method of basing general statements on accumulated observation of specific instances as against those that supported the exact opposite view of the new deductive method of Copernicus, Kepler and Galileo, the use of mathematics became an important theme in the understanding of natural phenomena. For these scientists, the human mind sees reality (nature) as an extension. It was 'matter' in motion, a vast mechanical system written in mathematical letters, extended in space and measurable in its dimensions, weight and velocity. As Jones puts it "for the qualitative and teleological conception of nature with which men of the middle ages had operated, there was substituted a quantitative and mechanical one". 6 The disagreement between the two new scientific methods encouraged philosophers to investigate the nature of these methods and their claims to certainty in knowledge. Their inability to find certainty led to skepticism, crises and confusion such that philosophers were divided on the proper method philosophy should pursue in its quest for knowledge. From now on, man became the center of reality.

In order to appreciate the source, scope and limits of the rationalist claim to knowledge and about the conditions of its validity which is at any rate an activity of the mind, we must attempt to examine the mind and its faculties as revealed in its cognitive activities. But first, let us begin with the emergence of rationalism and the Cartesian quest for certainty and thereafter go into a full illustration of the cognitive process of the understanding by which reason comes by our knowledge of reality.

\section{The Emergence of Rationalism}

In the midst of the above intellectual ferment, the French philosopher Rene Descartes $(1595-1650)$ initiated the seventeenth century rationalism as a cluster of ideas that add up the belief that the universe works the way a man's mind works when he thinks logically and objectively. Thus, man can understand everything in his experience as; he understands for instance a single mathematical or mechanical problem. Taken to an extreme, rationalism is Platonism. Its basic emphasis is the concept of innatism - the view that there are inborn ideas in our minds from birth and its assumption that we can grasp substantial truths concerning the nature of the external world through the rational capacity of the human mind to discover objective knowledge of reality in an aprioristic, deductive fashion comparable to the system of mathematics and geometry. The core of any rationalist theory, then, is that "a priori justification occurs when the mind directly or intuitively sees or grasps or apprehends a necessary fact about the nature or structure of reality"7. Descartes' theory of knowledge is rationalistic because he asserts that: 
By employing certain procedure of reason alone, we can discover knowledge in the strongest sense. Knowledge that can under no circumstances possibly be false ....He maintained that absolutely certain knowledge could be sought for only in the realm of the mind. ${ }^{8}$

To the rationalists therefore, "reason is the prima-matrix of human knowledge and with it alone, the certainty of knowledge is guaranteed". Apparently, this means the mind has the ability to reach beyond itself and grasp directly the necessary structure of the world. Proponents of some varieties of rationalism who held this view were Baruch Spinoza $(1632$ - 1677) and Gottfried Leibniz $(1646$ - 1716) whose attempt to grapple with the epistemological and metaphysical problems posed by Descartes led to the development of the fundamental principles of rationalism. Nicholas Malebranche's theory of knowledge as an earlier follower of Descartes for example, is of the contention that the human mind has its knowledge not from the senses but from an intuitive intellectual vision of truth in the Divine mind; Spinoza likewise regarded not the senses but only intellectual intuition and reasoning as the source of genuine knowledge while Leibniz believes that the perceptions of sense and the conceptions of reason are innate and derive their validity from a harmony pre-established between them and their objects by God - a sort of pan - psychism known as monadism.

\section{Descartes Quest for Cognitive Certainty}

The quest for achieving objective knowledge of reality was the principal philosophical problem that faced Descartes. The scientific laws and principles governing nature - typical of the scientific orientation influenced him to raise questions about the nature of the cognitive powers of the human mind which possess the ability of exploring the objective world. In addition to the methodological disagreement, mathematical knowledge as a model of certain knowledge in the sciences became fashionable. Its quality of precision, its axiomatic or self evident deposition influenced philosophers who began to acquire a scrutinizing outlook for the measurement of truth. It seems to Descartes, that by imitating the Galilean mathematical method, he hopes to rebuild the whole edifice of human knowledge on a solid foundation thus finding the certainty that had so far proved impossible. No doubt, Descartes' intention to put philosophy on better foundation is commendable but should we merely attempt to fit our knowledge of the world into mathematics? D. W. Hamlyn has observed that:

The question of the exact connection between mathematics and the world is a complicated one. Granted, however, that mathematical ideas have a certain precision not possessed by other ideas, it does not follow that we have a precise knowledge of the qualities of physical objects. ${ }^{10}$

Being convinced that what philosophy needs was a similar self evident mathematical axiom; Descartes assigned himself the task of laying a solid foundation on which the structure of what we know can be constructed. His desire for certain knowledge was critical to his general programme in epistemology. "He wants to answer to scepticism and he wants to do so within foundationalism, the view that all our knowledge of reality begins with some sort of self-evident beliefs". ${ }^{11}$ If Descartes were writing today, he would have discovered that some mathematical assertions have shifted.

Even in an area of human knowledge that various rationalists have used as a model - mathematics - there is some basis for disputing claims of absolute truth. The history of mathematics indicates that developments and changes have taken place in our mathematical knowledge, and that some theorems that were regarded as true have had to be modified or discarded. Even today mathematicians disagree as to which branches of the subject and which theorems, are really certain. ${ }^{12}$

Among philosophers themselves, there is no consensus as to the nature of mathematical reality. Many contemporary philosophers of mathematics have rejected the self-evident nature of axioms and mathematical knowledge. ${ }^{13}$ However, Descartes was convinced that our knowledge of mathematics is certain because our knowledge of it is innate. And because of the errors and deceptiveness attributed to our sense impressions, Descartes had to doubt all the knowledge and beliefs acquired through the senses. In his analysis into the nature

of the problem presented in his works the Discourse on the Method (1637) and Meditation on the First Philosophy $(1641)^{14}$, Descartes set up the objective of directing his rational faculty in the systematic analysis of truth and was guided in this investigation by the 'methodic doubt' - a systematic method designed to distinguish beliefs that were certain from those that could not be trusted. "Whatever, he could bring himself to doubt, he would doubt, until he saw no reason for not doubting it" $"$. 


\section{Methodic Doubt and the Criteria of Truth}

Descartes aim was not to introduce doubt about everything. The method of doubt which he used must be seen in relation to that of the sceptics. What the sceptics wonder about is whether we can attain truth, what Descartes plan was to use doubt to overcome doubt. According to Bennett Williams, "Descartes employed scepticism as a means of overturning scepticism". ${ }^{16}$ In Descartes' words:

Not that indeed I imitated, the skeptics who only doubt for the sake of doubting and pretend to be always uncertain; for on the contrary, my design was only to provide myself with good ground for assurance and to reject the quicksand and mud in order to find the rock or clay. ${ }^{17}$

He was seeking a solid foundation for all knowledge. Descartes felt that such a foundation could be secured only if we have to weed out the 'prejudices' or 'preconceived' opinion that we have uncritically accepted. He says:

I wish to give myself entirely to the search after Truth, I thought that it was necessary for me to take an apparently opposite course and to reject as absolutely false everything as to which I could imagine the least ground of doubts, in order to see if afterwards there remained anything in my belief that was entirely certain. ${ }^{18}$

In eliminating anything that can possibly be false, Descartes argues that what is left after the weeding process, what survives the doubt, will according to him provide the "foundations for the sciences that are stable and likely to last" ${ }^{\prime 19}$. But how can a method be based on doubt? It is possible, Descartes argues to imagine that everything he was aware of has no reality but

...The illusions of my dreams. But immediately afterwards I noticed that whilst I thus wished to think all things false, it was absolutely essential that ... this truth 'I think, therefore I am' was so certain and so assured that all the most extravagant suppositions brought forward by the skeptics were incapable of shaking it, I came to the conclusion that I could receive it without scruple as the first principle of the philosophy for which I was seeking. ${ }^{20}$

Here is the indubitable axiomatic truth 'cogito ergo sum' - 'I think, therefore I am'. Nothing, he says can cause us to deny the truth of this and it is true every time we think it; because we perceive its truth clearly and distinctly. Therefore, for Descartes whatever "we conceive very clearly and distinctly are all true." ${ }^{21}$ Clarity and distinctness became the sure marks of truth, that distinguishing characteristic by which we can tell truth from falsehood. He argues:

Certainly in this first knowledge there is nothing that assures me of its truth, excepting the clear and distinct perception of that which... I say is true, if it could ever happen that a thing which I conceived so clearly and distinctly could be false; and accordingly it seems to me that ... I can establish a general rule that all things, which I perceive very clearly and ... distinctly are true. ${ }^{22}$

This view for Descartes was purely rational and deductive. Only if we can discover an argument through the power of reason alone do we have a basis for accepting anything.

So that after having reflected well and carefully examined all things we must come to the definite conclusion that this proposition: I am, I exist, is necessary true each time that I pronounce it, or that I mentally conceived it. ${ }^{23}$

By this, Descartes maintains that our ideas considered on their own really exist. But errors arise when we make judgements regarding their correspondence to objects outside of us. This supposition leaves a number of important questions unanswered. It raises some questions as to how Descartes arrived at his conclusion that his acts of consciousness belong to an 'I' or a 'subject' who has them? Was he not making a judgement referring to an object? If Descartes was offering his conclusion as a form of inference drawn from a syllogistic form of argument, his conclusion would be problematic because he had already affirmed what he wanted to prove in the 'cogito' argument. Some philosophers think that Descartes is right in making this assertion. In their attempts to defend him, they maintain that the conclusion of the 'cogito' seems obvious. According to them, ideas consider in themselves, not referring to something else cannot strictly be false and if the 'cogito' is an inference having this character ascribe to it, then it is a single-step deduction having intuitive certainty - the highest degree of certainty possible in Cartesian epistemology. It is not implied that ideas considered in themselves not referring to 
something can be false. What this means is that any account of mental acts and consciousness must take cognizance of the independent existence of the external world, because it is from it that consciousness originate. At any rate, one wonders why Descartes could be so sure and certain about the existence of his mind which is invisible and intangible by imputing consciousness to it rather than affirming that it belongs to his body whose existence is much easier to prove. If all we are sure of is our existence, do we admit that the physical world and all the objects in it and even other people exist? The answer to this question can generate more difficulties than it resolves. For although it may be true that we ascribe mental states to others on the basis of our perceptual experience of their bodies, it is not clear how we are justified in doing so. What then is the evidential connection between bodily behaviour and mental states? How does perceiving the one justify an ascription of the other? Philosophers' failure to resolve these questions in a widely convincing fashion has prompted John McDowell to propose another track entirely. In a number of papers, he suggests that rather than arriving at our beliefs about others mental state by inference from their bodily behaviour, we actually perceive the fact that they have mental states "directly ... as an input to the senses" 24

\section{The Wax Experiment}

In his own explanation, Descartes adopts metaphysical dualism, a philosophical concept that regards both mind and body as equally real. Though, the former as a "thinking substance" (res cogitans) has priority over the latter which is an "extended substance" (res extensa). Descartes' argument is that our knowledge of bodies or senses together with their extended nature (though unreliable) play a secondary role in our knowledge of the world and therefore cannot be as certain as the knowledge of our thinking nature. In experimenting with the wax, he says.

Let us take, for example, this piece of wax: it has been taken quite freshly from the hive, and it has not yet lost the sweetness of the honey which it contains; it still retains somewhat of the odour of the flowers from which it has been culled; its colour, its figure, its size are apparent; it is hard, cold, easily handled, and if you strike it with the finger, it will emit a sound... All things, which are requisite to cause us distinctly to recognize a body, are met with it. But notice that while I speak and approach the fire, what remained of the taste is exhaled, the smell evaporates, the colour alters, the figure is destroyed, the size increases, it becomes liquid, it heats, scarcely can one handle it, and when one strikes it, no sound is emitted. (Now Descartes asked :) Does the same wax remain after this change? ${ }^{25}$

With this experiment, Descartes conclude that the essence of the wax does not consist in it sensory or bodily qualities (colour, smell, hardness etc.) because these qualities can change and yet the wax remains the same. They are therefore, not important to be wax. The only unchanging, permanent quality of the wax is its 'extension' which the senses are not capable of given. We can be sure then of mind and matter completely different in kind (dualism) as ultimate realities. By this, Descartes was driven from his famous 'cogito ergo sum' - 'I think, therefore I am; the knowledge of the self, the first principle from which we can discover the truths of other statements and goes ahead to build a system of philosophy that deductively prove the existence of God and the external world. For Descartes, then, knowledge of the self is prior to knowledge of God and both the self and God are prior to our knowledge of the external world. Thus, Descartes concludes that: (i) the essence of a person is thought. (ii) we know reality not through the senses i.e. reality is not given to us through sensory qualities but through the mind (the understanding).

The implication of Descartes view is that thought is a generic notion involving all acts of consciousness like emotions, desires, volitions, deliberations, feelings and even imagination. Descartes' argument is that our acts of consciousness do exist and for it to exist, it must exist in a conscious being. But does thinking necessarily require a thinker? Perhaps, all that Descartes may be justified in asserting is that he is a thinking 'ego' or 'thinking self'. Granted that humans exist as beings to think and not think to exist, what then is the role of the human mind for the rationalist in the knowing process? How does the human mind come by our knowledge of reality or better still what is the nature of the human understanding?

\section{Rationalists' Concept of Mental Activity}

From the foregoing discussions, we can infer that the entire thrust of rationalism is that it purports to explain a priori knowledge by means of the mind's confrontation with necessity. This means that the human mind has a privilege access to reality. The rationalists whose first notable representative - Descartes - did much towards concentrating all subsequent philosophical speculation explicitly on the problem of the possibility and limit of human certitude. His desire for certainty in making a clean sweep of all previous philosophical tradition, 
trying to assume absolutely nothing and laying down as the basis of all knowledge his own consciousness that he was doubting everything led him to inquire into the supposed features of our mental perceptions. Descartes' theory of mind therefore consists in explaining the cognitive process by which the human mind comes by our knowledge of reality. He "insists on the necessity of method, on systematic and orderly thinking" argument is that our minds naturally possess two "mental operations (intuition and deduction) by which we are able, entirely without fear of illusion, to arrive at the knowledge of things". ${ }^{27}$ By intuition, Descartes means the intellectual power by which the mind grasp clear and distinct ideas while by deduction, the mind makes inferences and draw necessary implications from such truths. It is Descartes' contention that apart from these two mental operations of the mind, other routes to our knowledge of things, "should be rejected as suspect of errors and dangerous" 28 . For him, the only true concepts, the only clear and distinct ideas are those innate in the mind. According to Descartes, our minds come stocked with a variety of intellectual concepts - ideas whose content derives solely from the nature of the mind. This store house includes ideas of mathematical principles (i.e. numbers, lines, triangles etc), of logical concepts (i.e. contradiction, necessity etc), of moral concepts (i.e. goodness, beauty, virtue, piety etc) and metaphysical realities (i.e. identity, substance, causality etc). They are part of our rational nature in such a way that while experience may stimulate the process by which they given to our consciousness, it does not account for the origin of the concepts or determine the information they contain. This means that the immediate objects of our perception are for Descartes ideas. According to him:

On the contrary, I have noticed that in many cases there was a great difference between the object and its idea ... the principal error and the commonest we may meet which consists in my judging that the ideas which are in me are similar or conformable to the things which are outside of me, for without doubt, if I considered the ideas only as certain modes of my thoughts, without trying to relate them to anything beyond they could scarcely give the material for error ${ }^{29}$.

The above view implies that Descartes takes "the word 'ideas' to refer to whatever is immediately perceived by the mind" 30 . But if our minds have to rely upon ideas as representations, should we say we are in a direct confrontation with reality?

In his classic paper 'Clearness and Distinctness in Descartes', Alan Gewirth raises very critical objection to Descartes' position. Ideas he argues have intentionality in that they represent or refer to things and since Descartes had pointed out that "there were objects (outside the human mind) from which these ideas proceeded" "31, clearness and distinctness for Gewirth are qualities internal to ideas and perceptive acts. In this way, Gewirth is of the opinion that clearness and distinctness belong to the psychological aspects of our thoughts and not the logical as proposed by Descartes which makes it difficult to see how they could be the criteria of truth. For an idea to be clear and distinct Gewirth believes there must be what he calls an “ 'equality' of its direct and interpretative contents" ${ }^{32}$ and for him, this turns out to be a logical and not a psychological relation - one that depends on an analysis of the representational content of the idea, as different to the subjective characteristics. For Gewirth, this still does not explain why Descartes says an idea is clear and distinct. Here, Gewirth explains Descartes method by referring to his argument of the wax experiment in the Second Meditation which is supposed to help the meditator among other things 'to dig out' or achieve a purely mental scrutiny of what is innate. Starting with sensory and bodily qualities of the wax which can change, the meditator is made to grasp the more constant, permanent feature of the wax by discarding those features that are not essential to the wax until "a direct content is attained which survives every reductive device remaining so long as the object can be conceived and without which the object can no longer be conceived" ${ }^{33}$. Even at that, there is still a problem between the ideas that are directly perceived by the mind and the real nature of the object. It is to ensure that ideas correspond to reality that the concept of God in Descartes' philosophy becomes more relevant. Thus, for Gewirth "the methodological orientation must be supplemented by a metaphysical one culminating in the divine guarantee" 34 . As Descartes himself says "God ... who being supremely perfect ... cannot be the cause of any error; and consequently we must conclude that such a conception (clear and distinct) is true",35. It does seem that Descartes' reference to God as the guarantor of human knowledge is a problematic feature of the Cartesian circle.

Like Descartes, Spinoza was “impressed by Galileo's successful application of mathematics to the study of nature". ${ }^{36}$ He argues that "every definition or clear and distinct idea is true" ${ }^{37}$. But how can the human mind know the right definition or clear and distinct idea? Spinoza's theory of mind is based on the view that if the intellect operate with clear and distinct ideas of God and from here deduces other logical ideas, it cannot be wrong because it is operating according to the nature of reason. From this conclusion, Spinoza argues that there is only one substance God whose existence is immanent and one and the same thing with the universe "Whatever is, is in God and without God nothing can be or be conceived". ${ }^{38}$ This makes all our ideas innate. Spinoza tells us that an adequate idea of nature must begin with an adequate knowledge of God. 
Our mind must deduce all its ideas, from the ideal which represents the origin and source of the whole of nature, so that, it may itself become the source of other ideas. ${ }^{39}$

The knowledge of nature or science will then be the knowledge of God or theology. Spinoza identifies three processes by which the human mind takes in arriving at knowledge of reality. These are imagination, reason and intuition.

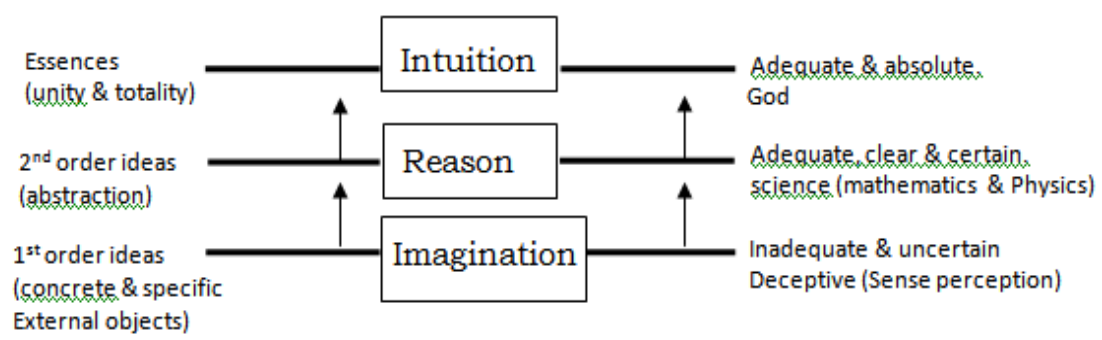

He argues

.. The intellect, by its native strength, makes for itself in intellectual
instruments, whereby it acquires strength for performing other
intellectual operation, and from these operations gets again fresh
instruments or the power of pushing its investigations further and thus
gradually proceeds till it reaches the submit of wisdom.

That our minds derive ideas from sensations are for Spinoza objects of imagination. These ideas which are very concrete and specific reflect bodily changes and states produced by other external bodies and do not spring from the active power of the mind, and because they are derived by logical deduction from other ideas, they are uncritical, vague, inadequate, "very uncertain, (faulty) and indefinite...." Fi Faulty because reports based on the testimony of others are often distorted, hence these unanalyzed ideas cannot guarantee objective knowledge because they come through the senses which are deceptive and fallacious and gives us only a superficial and very often confused picture of reality.

The second level of perception which involves scientific knowledge is the level of reason. Spinoza tells us that the human mind here has the capacity to reflect on the first order ideas and "gives us the idea of the thing sought, ... yet (it is) not by itself sufficient to put us in possession of the perfection we aim at" ${ }^{42}$ According to Spinoza, the reflection on what is common among objects give rise to second order ideas which he call 'common notion'. Among the second order ideas, he mentions number, notion or rest. Knowledge at this stage is adequate and necessarily true because they are both contained in God and in particular objects. By advancing from the first to the second level of knowledge, one passes from logically related impressions and confused ideas to logically related and clear propositions and adequate ideas. Furthermore, one abandons the sense perception and imagination for the abstract generality of mathematics and physics. This is how the external world is translated into the objects of the mind. But if the mind has the strength to produce ideas within itself which are simple, adequate and true as Spinoza argues, why does it have to reflect on the ideas from external objects before it can know itself? Or if the mind with its native strength can produce ideas which are self-evident and true, why does it have to rely on the external world in order to produce second order ideas which are adequate? And what is the relationship of Spinoza's self-evident ideas to the external reality which is always undergoing change? The third level of perception which guarantees an adequate and absolute knowledge is intuition. This "mode alone (according to Spinoza) apprehends the adequate essence of a thing without danger or error" ${ }^{\text {" }}$. By this vision, the human mind grasps the ultimate nature of reality in all its unity and whole. Thus, Spinoza asserts that this kind of knowledge "proceeds from an adequate idea of formal essence of certain attributes of God to the adequate knowledge of the essence of things". ${ }^{44}$ Though, regarded as one of the most consistent philosophers often given the label of a 'pantheist', yet like Descartes, he fell into a vicious circle. While maintaining that it is through reasoning that the human mind can discover adequate truth about reality, he argues that reasoning must begin with an adequate idea of God.

Like other rationalists, Leibniz too was convinced about the certainty of mathematical knowledge having seen that the scientific achievements of the early modern period made him unable to abandon the belief "that mathematics is the grammar of nature". ${ }^{45}$ In line with Descartes and Spinoza, Leibniz assumes clarify and distinctness as the criteria of truth. He argues that "all knowledge is either obscure or clear and clear knowledge is either inadequate or adequate ... the most perfect knowledge is that which is both adequate and intuitive". 46 Leibniz holds that the human mind endowed with innate ideas is capable of attaining certain knowledge of 
reality. In his own words, Leibniz replies the empiricists as he affirms the strong belief of the rationalists on innate ideas.

Our disagreements concerning points of some importance. There is the question whether the soul in itself is completely blank like a writing tablet on which nothing had yet been written - a tabula rasa - as Aristotle and the writer of the Essay maintain, and whether everything which is inscribed there comes solely from the senses and experience, or whether the soul inherently contains the source of various notions and doctrines, which external objects merely rouse up on suitable occasions, as I believe and as do Plato and even the schoolmen. ${ }^{47}$

According to Leibniz, Descartes distinction between mind and matter is unwarranted since the world is composed of simple and immaterial substance called Monads derived from the Greek word monads "which signifies unity or that which is one" ${ }^{48} \mathrm{He}$ argues that the world of spatial and invisible phenomena is the translation of the monads immaterial structures. Each 'monas' is said to be independent of the other and since they are individual substances and contain everything in themselves for their self development, they have no causal relationship with others nor do they interact with each other. But if we assume as did Leibniz that monads are self-enclosed or self sufficient and do not interact with others, how then one may ask do they communicate? How will they know about each others existence? If a monad cannot move out of itself, but can only reflect on its own ideas, this means if exist alone - a position that leads to solipsism which affirms one's existence, yet denying the existence of other beings. It does seems that Leibniz may have realized the implications of this assumption when he posits that the co-existence of the monads is a pre-established harmony by God who always make things in our minds correspond to external things; thus explaining the inter-relationship between all monads and the universe.

It is a popular perception that to give an adequate description of the universe, one must take into cognizance the existence of our consciousness and the physical world. For Leibniz, the universe is an association of souls existing in harmony because God has made it so. He expresses this point in a logical way by distinguishing between truths of reason which are analytic because their predicates are contained within their subjects while truths of fact are synthetic because they are empirical. Leibniz argues that truths of fact are synthetic because men do not know all the predicates a thing contains. Only God knows a priori all the predicates of things or the attributes of substance and for this reason all truths of fact and truths of reason are analytic to God. Leibniz, therefore argues that it is our ignorance and limitations that prevent us from perceiving all the predicates of things and hence our subsequent division of knowledge into analytic and synthetic. On this basis, he concludes that even if we cannot know all reality as God knows it, yet the human mind contains certain innate ideas and given particular situations, experience will make these innate truths self-evident.

Leibniz's theory of mind is today criticized by many for the lack of originality. It is for the most part 'an old wine in a new wine skin'. He accepts the greater part of the earlier attempts in explaining how the human mind comes by our knowledge of reality especially that of the Scholastics, of Descartes and of Spinoza saying that "nearly all of the means which have been employed (in arriving at our knowledge of reality and) to prove the existence of God are good and might be of service, if we would perfect them...."49 In this respect, Jones says of him:

Leibniz's reality ended like Spinoza with one substance, the only difference being that whereas Spinoza's 'one' was a self transcending whole, Leibniz's was a whole consuming self. But whether we have a world that has swallowed the self or a self that has swallowed the world seems almost a matter of indifference. ${ }^{50}$

It should be clear from these analyses that for the rationalists - Descartes, Spinoza and Leibniz - the human mind arrives at the knowledge of reality by pure reason alone having been influenced by the absolute nature of mathematics whose propositions are constructed from simple concepts, they however differ radically as regards what constitutes the nature of this reality. For Descartes, thought and extension are the two basic substances $-\mathrm{a}$ dualism. For Spinoza, reality is one and is God or Nature - a monism while for Leibniz reality is of only one kind of substance, the monad. Yet, there are different kinds of monad accounting for the various elements in nature - pluralism.

\section{Thinking, Reasoning and Knowing in Descartes}

Descartes' attempt to differentiate between thinking, reasoning and knowing sets a fundamental role for the mind in the knowing process. The distance that intervenes between the mind and external objects is one of the main aspects of subjectivization of thinking and knowing that occurs with Descartes. With him, thinking 
achieves certainty only when the mind takes itself as its object. A further aspect is that thinking becomes identified with a subject, a self. Infact, according to Descartes the self is a thinking substance. It is an exclusive category of the human mind achieved through the process of reflection. He argues:

By the word thought I understand all that we are conscious as operating in us. And that is why not only alone understanding, willing, imagining, but also feeling are here the same thing as thought ${ }^{51}$.

The mind is said to possess an exclusive function of thought. It is the reflective process of the mind that leads to the knowledge of the self such that when the mind thinks about itself, the mind achieves the knowledge of the self - the knowledge of the cogito- the 'I think'.

But what then am I? A thing which thinks. What is a thing which thinks? It is a thing which doubts, understands (conceives), affirms, denies wills, refuses which also imagines and feels. ${ }^{52}$

For the rationalist then, more so for Descartes, thinking is not per se knowing. Knowing is only achieved through reasoning which involves both predication and argumentation. Reasoning is not according to Descartes a collection of thoughts. It is the formation of concepts, the predication of properties of an object and deduction from first principles (axiomatic truths) which are grasped by intuition or introspection. As the gateway to the world, predicating properties of an object is a mental activity that occurs within specific conditions. Sensation is not sufficient for predication because in front of an object, we may have infinity of sensations, infinity of possible images. For example, I may have many infinite sensations/images concerning a table but to posit an object, I have to form a concept, a unifying/unified idea. For Descartes, concepts cannot be derived from sensations. In themselves, they are purely mental entities which are innate in us. Thus, with the rationalists, we begin to have a conception of reasoning and knowing as a form of 'production', as a productive activity. The human mind is like a 'machine' that produces the raw materials for knowledge within its own operations. Since the only grounds for certainty is self knowledge, the process whereby the mind grasps certain innate concepts is such that the end result of the knowing process is a fixed set of concept (the self, God, mathematical and geometrical truths and the truths of logic). For the rationalists therefore, knowledge is not state but an activity - a direction of the mind which can be guided or directed to form clear and distinct ideas.

Minds as Productive

(Knowledge of the external world are generated from within as innate ideas)
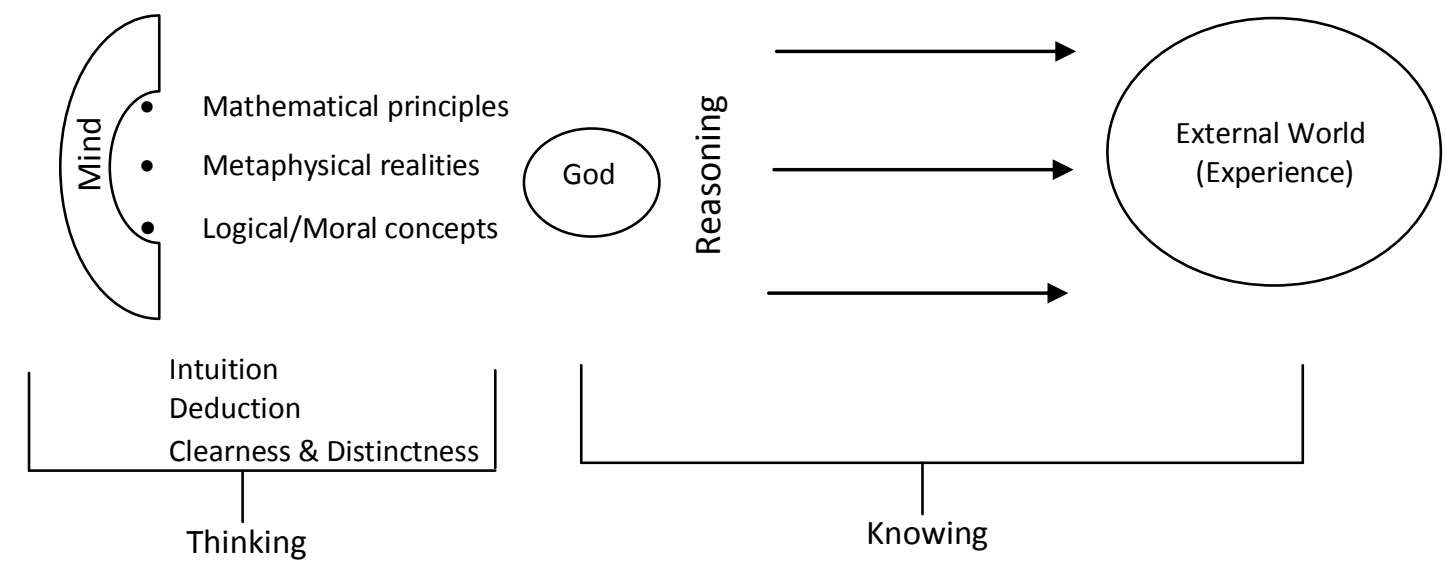

\section{Descartes Influences on Subsequent Philosophy}

By investigating the method of doubt and by showing that knowledge begins from the subjective mind, Descartes sets up reactions for speculations in the theory of mind and consciousness. Though many scholars regard Descartes' philosophical doctrines as suspect, yet there are others who by no means represent a small group of modern philosophers whose work today might fairly be described as Cartesian. But irrespective of whether or not his conclusions are accepted, Descartes' thinking has had a pervasive and enduring effect on the very structure of philosophical agenda. Jones supports this assertion when he says:

... if Descartes did nothing else, he made clear the formidable task that faced his successors. But, as a matter of fact, he did much more. His formulation of the basic question confronting philosophy seemed so sensible that it determined the course of philosophical development for 
more than a century and left its mark on the whole subsequent history of philosophy. All his immediate successors took it more or less for granted at least as a starting point, that there is a material world and that there is a self that knows this world ... Even those who were not happy about all of Descartes conclusions tended to start with the Cartesian compromise and to work out ad-hoc solutions for each of the problems that emerged as they proceeded. Thus, in the course of time, theories were developed that were very different from Cartesianism in their detailed conclusions... though they all started out from a Cartesian basis. $^{53}$

With enormous doubt about the rationalists' theory of mind, proponents of the British empirical tradition - John Locke (1632 - 1704), George Berkeley (1685 - 1753) and David Hume (1711 - 1776) have challenged the rationalists' mental claims. Rather than accepting that our knowledge of the world begins from the subjective self; thus emphasizing the productive role of the mind in the knowing process, these philosophers by the second half of the seventeenth century began to work out an alternative theory of mind which was consistent with the data acquired through sense experience that provided the mind with far more information about the world than all the alleged claims of the rationalists. Though, Bacon to Locke to Berkeley to Hume and many other successors like Kant are seen as inheritors of the Cartesian tradition in philosophy, they however differ in their separate ways. Bacon for example, who was the first important proponent of the empirical approach in the seventeenth century England had worked out the table of induction and strongly criticized rationalism in all its forms, Locke traced all ideas to experience and argued against innate ideas while Berkeley indentified being with the perceived (a ditch of idealism) and with Hume usually regarded as the most consistent British philosopher who continued by analyzing the structure of the mind in terms of Locke's emphasis - empiricism had reached a point of total crisis ending in skepticism. While the empiricists' reactions to Descartes rationalism were united in their general tendency to see the mind as playing a passive, mechanical role in the knowing process, Kant too had no other option than to get back to Descartes' in other to formulate the active role of the mind in the critical philosophy.

\section{Conclusion}

It is a manifest that knowledge involves a relation between the knowing subject and the known object (though, the majority of the epistemological attention has been devoted to the subject side of that relation). Citing the Cartesian example, this paper has given the rationalists account of how reason works. Beginning with the assumption that rationalism is consistent with the foundationalist theory of epistemic justification, the work showed us how Descartes as a rationalist fashioned a new structure for philosophy that was influenced by the progress and success of science and mathematics. His purpose was to build the whole edifice of human knowledge upon a solid and secured foundation of complete certainty. Reviewing his beliefs that some were more or less justified than others, he resolved to order these cluster of beliefs so that the certainty of one proposition may follow from another. In the Meditations, he showed the nature of our cognitive process and of realities as known objects of our contemplation. He argued that thought is the foundation of reality; that the only thing we can be certain of is the fact of our own existence - an investigation he summed up in his famous maxim 'cogito ergo sum'. According to Descartes, except a man is conscious of his own existence, he cannot be aware of the existence of any other reality outside the mind.

For Descartes, consciousness is the activity and quality of a subject that exists; a subject which has the potential to perform all acts of thinking including the physical and mental images and the ability to organize and interpret all the complex activities of the mental and physical states of our experience. His theory of mind therefore was to show that our knowledge of the external world begins from the subjective self. In formulating the criteria of truth as clarity and distinctness by which the human mind come by our knowledge of reality, Descartes argued that the senses are grossly unreliable in supplying us with information about the world. According to him, there are sundry rational principles immanent in the mind in such a way that we are capable of forming ideas that reflect the true nature of reality. This means the mind possess innate capacity to generate ideas within it. Although, Descartes' philosophy has raised very serious problems about our knowledge of the world, he represents a very important figure and a great influence in the long distinguished history of ideas. In fact, without the enormous impact that Descartes made in philosophy, the epistemological problems as to what count as genuine and reliable knowledge, the bifurcation of substance into thought and extension, mind and matter, corporeal and incorporeal, the relationship between theory and facts (practice) in scientific inquiry, the role of the subject and its relation to the objectivity of science would not have been thoroughly investigated. Descartes' approach to the philosophy of science and epistemology has no doubt played a prominent role in shaping subsequent philosophical thought and writing. 


\section{References}

[1]. The term Cartesian is from the Latin word 'Cartesius'. It is often used as a nickname for Descartes' philosophy. In the seventeenth century Descartes' writings were published in Latin the official language used during this period.

[2]. Robert Pasnau, Theories of Cognition in the Later Middle Ages (New York: Cambridge University Press), 1997, p.9

[3]. "Considera igitur hanem trium potentiarum operations et habitudines, et videre poteris Deum per te tanquam per imaginem, quo est videre per speculum in aenigmate" ( itinerarium mentis in Deum III, 1)

[4]. "Ipsum enim lumen intellectual quod est in nobis, nihil est aliud quam qaedam participate similitude luminis increate" (ST 1a 84.5C).

[5]. W.T. Jones, A History of Western Philosophy, Vol III (Hobbes to Hume) $2^{\text {nd }}$ ed., Revised (New-York: Harcourt Brace Jovanovich 1952, p. xix

[6]. Jones, A History of Western Philosophy, Vol III (Hobbes to Hume) $2^{\text {nd }}$ ed., Revised, p. 115

[7]. Laurence BonJour, In Defense of Pure Reason, (Cambridge: Cambridge University Press), 1998, pp. 15 - 16

[8]. Richard H. Popkin et al, The History of Skepticism From Erasmus to Descartes, (New - York: Har per \& Row) 1968, p. 189

[9]. A. J. Ayer, The Problems of Knowledge. (Londom: Penguin Books) 1956, p.54

[10]. W.T. Hamlyn, The Theory of Knowledge. (London: Macmillan Press), 1970, p. 88

[11]. Peter Markie "The Cogito and its Importance" in Descartes ed. by John Cottingham, Oxford: Oxford University Press, 1998, p.51

[12]. Richard Popkin et al, The History of Skepticism from Erasmus to Descartes p. 169.

[13]. Philosophers of mathematics have disagreed about the nature of mathematical reality. One group holds that it is mental and that we in some sense construct it - this group maintains that sensory observation does not justify mathematical belief - a view which claims that our knowledge of mathematical premise is non-empirical. Examples of this theory include Godel's epistemological Platonism, intuitionism etc. Other philosophers have maintained that mathematical reality lies outside and independent of us. This view claims that the justification of mathematical entities requires sensory evidence. Hugh Lehman calls it the realist interpretation of mathematical knowledge. Chief spokesman are John Stuart Mill, Hugh Lehman etc. There is still another alternative version of the view that mathematical truth is empirical. This position holds that though mathematical propositions are true, they do not imply the existence of mathematical entities, but of the forms whose elements are mere symbols/strokes or meaningless marks to be operated upon by a set of convention or fixed rules. This view is known as formalism. Earlier formalists held that the subject matter of mathematics consists of tangible signs. Some modern exponents are D. Hibert and H.B Curry.

[14]. The full title is Discourse on the Method of Rightly Conducting Reason and Reaching the Truth in the Sciences (published anonymously in Leiden June, 1637) While the First Edition of the Meditation was published in Latin in 1641, second edition in 1642 and translated in French in the same year.

[15]. K.T. Gallagher, The Philosophy of Knowledge. (New York: Sheed and Ward), 1964, p. 5.

[16]. B. Williams, Descartes: The Project of Pure Enquiry. (Harmondsworth: Penguin), 1978, p. 181.

[17]. Rene Descartes, 'Discourse on the Method,' The Philosophical Works, Vol.1 Trans. by Elizabeth S. Haldane \& G.R.T. Ross (Cambridge: Cambridge University Press) 1986, p. 999.

[18]. Descartes, 'Discourse on the Method,' The Philosophical Works. p. 101.

[19]. Descartes, 'Discourse on the Method,' The Philosophical Works. p. 101.

[20]. Descartes, 'Discourse on the Method,' The Philosophical Works. p. 101

[21]. Descartes, 'Discourse on the Method,' The Philosophical Works. p. 102.

[22]. Descartes, 'Meditations on First Philosophy,' The Philosophical Works. p. 158

[23]. Descartes, 'Meditations on First Philosophy,' The Philosophical Works. p. 150.

[24]. John McDowell "On the Reality of the Past" in Christopher Hookaway \& Philip Pettit, eds., Action and Interpretation. (Cambridge: Cambridge University Press), 1978, p. 140.

[25]. Descartes, 'Discourse on the Method,' The Philosophical Works. p.154

[26]. Samuel E. Stumpf, Philosophy, History and Problems $3^{\text {rd }}$ ed., (New York: McGraw - Hill), 1989, p.238

[27]. Descartes, 'Rules for the Direction of the Mind,' The Philosophical Works. p.7

[28]. Descartes, 'Rules for the Direction of the Mind,' The Philosophical Works. p. 8.

[29]. Descartes, 'Meditations on First Philosophy' The Philosophical Works, pp. 160-161

[30]. Descartes, 'Meditations on First Philosophy', The Philosophical Works, p. 163

[31]. Descartes, 'Meditations on First Philosophy', The Philosophical Works, p. 164

[32]. Allan Gewirth 'Cleanness and Distinctness in Descartes' in Descartes ed. by John Cottingham, p. 87

[33]. Gewirth 'Cleanness and Distinctness in Descartes' in Descartes ed. by John Cottingham, p. 96

[34]. Gewirth 'Cleanness and Distinctness in Descartes' in Descartes ed. by John Cottingham, p. 98

[35]. Descartes, 'Meditations on First Philosophy,' The Philosophical Works, p. 178

[36]. Jones, A History of Western Philosophy, Vol. III (Hobbes to Hume) $2^{\text {nd }}$ ed., Revised, p.193

[37]. Benedict De Spinoza, The Chief Works, Translated from the Latin with an Introduction by R. H. M. Elwes, Vol. I \& II (New York: Dover Publications), 1951, p.38

[38]. Spinoza, 'The Ethics' The Chief Works. p. 55

[39]. Spinoza, 'On the Improvement of the Understanding,' The Chief Works. p.15

[40]. Spinoza, 'On the Improvement of the Understanding,' The Chief Works. pp.11-12

[41]. Spinoza, 'On the Improvement of the Understanding,' The Chief Works. p.11

[42]. Spinoza, 'On the Improvement of the Understanding,' The Chief Works. p.11

[43]. Spinoza, 'On the Improvement of the Understanding,' The Chief Works. p.11

[44]. Spinoza, 'On the Improvement of the Understanding,' The Chief Works. p.15

[45]. G.W. Leibniz, Philosophical Papers and Letters. Vol. 1, A Selection Trans. \& ed. by Leroy E. Leomker, (Chicago: University of Chicago Press), 1956, p. 50

[46]. Leibniz, 'Of Universal Synthesis and Analysis' Philosophical Writings. Translated by Mary Morris et al (London: J.M. Dent \& Sons), 1973, p.14

[47]. Leibniz, New Essays on Human Understanding. Trans. \& ed. by Peter Remnant et al (Cambridge: Cambridge University Press), 1982 , p.48

[48]. Leibniz, 'Principles of Nature and of Grace Founded on Reason,' Philosophical Writings. p. 195

[49]. Leibniz, Philosophical Papers and Letters p. 232

[50]. Jones, A History of Western Philosophy, Vol. III (Hobbes to Hume) $2^{\text {nd }}$ ed., Revised, p. 236

[51]. Descartes 'The Principles of Philosophy', Part 1, Principles IX, The Philosophical Works, p. 222

[52]. Descartes, 'Meditations on First Philosophy', The Philosophical Works, p. 153

[53]. Jones, A History of Western Philosophy, Vol. III (Hobbes to Hume) $2^{\text {nd }}$ ed., Revised, p.189 